DOI: https://doi.org/10.24144/2409-6857.2018.1(51).288-291

УДК 338.4

\author{
Шевчук Н.С.
}

\title{
МЕТОДИЧНІ АСПЕКТИ УПРАВЛІНСЬКОГО АНАЛІЗУ СУЧАСНИХ БУДІВЕЛЬНИХ ПІДПРИЕМСТВ
}

\begin{abstract}
У статті досліджено напрямки удосконалення аналітичного інструментарію управління бізнес-прочесами як основи формування бізнес-иілей для підприємств будівельної галузі. Запропоновано методичні підходи до систематизації показників оцінювання ефективності діяльності підприємств з урахуванням особливостей будівельної галузі, а також підходи до вибору поточних та стратегічних критерїв очінки фінансовогосподарської діяльності підприємств, зокрема за доходостворюючими, забезпечуючими та розвиваючими видами процесів.
\end{abstract}

Ключові слова. Управлінський аналіз, система показників, бізнес-прочеси, будівельні підприємства

Постановка проблеми. На сучасному етапі розвитку економіки країн світу відбувається завершення одного глобального відтворювального циклу і настає інший на якісно новій технологічній, інституціональній і фінансовій основі, який залучає до своєї орбіти i високорозвинуті країни, i країни, що розвиваються. Шляхом відновлення пріоритету розвитку реального сектору економіки на новій технологічній основі відбувається зміна глобальної господарської моделі, яка дає шанс подолати негативні наслідки світової кризи $[1, \mathrm{c.3}]$. Проблема підтримання конкурентоспроможності та фінансової стійкості є особливо актуальною для підприємств будівельної галузі у зв'язку із впливом світової фінансової кризи на українську економіку, зокрема на таку сферу реального сектору економіки, що характеризується використанням значних обсягів кредитних ресурсів. Аналіз економічного потенціалу 3 позиції конкурентоспроможності дозволяє організації приймати управлінські рішення щодо ефективного використання всіх наявних ресурсів 3 метою досягнення надійності підприємства як ділового партнера, підвищення його конкурентоспроможності та інвестиційної привабливості. Необхідність поглиблення та конкретизації методичних підходів управлінського аналізу диктується тим, що результати такого аналізу можуть бути основою для порівняльної характеристики комерційної діяльності конкуруючих підприємств, служити основою для вибору перспективних варіантів розвитку підприємств будь-якої галузі.

Як відомо, ефективність всієї системи економіки держави залежить від стану будівельної галузі, оскільки капітальне

(C) Шевчук Ніна Сергіївна, к.е.н., доцент, Одеський національний економічний університет, м. Одеса, тел.: 0504921988, email: shevchuknina23@gmail.com будівництво створює велику кількість робочих місць та споживає продукцію багатьох галузей економіки. Негативні тенденції падіння індексів будівельної продукції (таблиця 1) поступово змінюються на позитивну динаміку показників обсягів продукції будівництва, як в цілому, так і за окремими видами (будівлі житлового та нежитлового призначення, інженерні споруди) та для сучасного стану української економіки позитивні тенденції у будівельній галузі сприятимуть зростанню рівня технологічного оновлення діючого виробничого потенціала та підвищенню попиту на продукцію підприємств малого бізнесу.

Вищеозначене потребує удосконалення методів управлінського аналізу фінансовогосподарської діяльності будівельної організації та впровадження системи аналітичних показників діагностування ефективності бізнеспроцесів будівельних підприємств як основи прийняття обгрунтованих управлінських рішень.

Аналіз останніх досліджень i публікацій. Теоретичною базою дослідження $\epsilon$ вітчизняний та закордонний досвід науковців 3 вирішення проблем процесного управління, аналізу бізнес-процесів: Нортон Д, Каплан Р., Харрингтон Х., Харрингтон Дж., Метеленко Н., Мних $\epsilon$, Гевко I. та ін. Значний вклад до формування та розвитку аналітичної бази управління підприємствами будівельної галузі внесено науковцями: Петрищенко Н., Сіміоновим Р., Пономарьовою Н., Куліковою Л. та ін. Велика кількість наукових публікацій, що розкривають теоретичні, методологічні та методичні питання ефективного управління бізнес-процесами, $є$ основою формування галузевих методик аналізу, зокрема потребують подальшого дослідження питання формування інструментарію управлінського аналізу для сучасного функціонування будівельного бізнесу. 
Таблиця 1

Індекси будівельної продукції за видами*[2]

(у\% до попереднього року)

\begin{tabular}{|c|c|c|c|c|c|}
\hline Роки & \multirow{2}{*}{$\begin{array}{c}\text { Будівництво, } \\
\text { всього }\end{array}$} & Будівлі & \multicolumn{2}{|c|}{ У тому числі } & \multirow{2}{*}{ Інженерні споруди } \\
\cline { 4 - 5 } & 120.0 & 114.9 & 101.7 & 122.1 & 124.4 \\
\hline 2011 & 92.7 & 93.9 & 93.5 & 94.1 & 91.7 \\
\hline 2012 & 89.0 & 96.6 & 111.3 & 90.0 & 82.8 \\
\hline 2013 & 79.6 & 79.6 & 103.5 & 66.3 & 79.7 \\
\hline 2014 & 87.7 & 91.9 & 98.9 & 85.8 & 83.7 \\
\hline 2015 & 117.4 & 120.7 & 117.8 & 123.7 & 114.0 \\
\hline 2016 & & &
\end{tabular}

*Без урахування тимчасово окупованої території Автономної Республіки Крим та м. Севастополя, за 2014-2016 роки також без частини зони проведення антитерористичної операції.

Формулювання цілей статті. Основна мета дослідження - пошук методичних підходів 3 удосконалення управлінського аналізу бізнеспроцесів за видами виробничо-господарської діяльності підприємств будівельної галузі.

Опис основного матеріалу дослідження. Аспекти управлінського аналізу залежать від різних підходів до управління в будівельній галузі. В літературі виділяють три підходи в залежності від охоплення різних об'єктів управління: 1) при галузевому управлінні виконавців будівельних робіт, тобто підрядні організації разом із їхньою технічною базою та проектуванням; 2) при територіальному управлінні - багатогалузевий будівельний комплекс, який включає додатково промисловість будівельних матеріалів і виробів; 3) при інвестиційному підході - по ланцюжку: від замовників (інвесторів), усіх виконавців будівельних і небудівельних робіт і послуг у процесі підготовки та будівництва об'єктів до суб'єктів, які експлуатують будівлі та споруди, використовують їхні корисні властивості або якість [3]. Оскільки, перші два підходи характерні для централізованої планової економіки, то зосередимо увагу на інвестиційному підході як прийнятному для організації управління в ринкових умовах, що охоплює всіх учасників різних форм власності та вказує на кінцеву мету їхньої взаємодії - створення ефективних в експлуатації будівель і споруд.

Особливості, що притаманні діяльності будівельного підприємства, впливають на здійснення основних завдань підприємства (бізнес-цілі), тому вони мають знайти відображення у системі показників-індикаторів аналізу бізнес-процесів. Зокрема, це наступні особливості:

1) Розбіжності в часі процесів будівництва об'єктів та звітного періоду. Оскільки більшість показників можна розрахувати тільки по завершенні звітного періоду, виникає необхідність аналізу витрат у розмежуванні - за період та по об'єктах;
2) Бізнес-процеси охоплюють значну площу 3 використанням великої кількості будівельної техніки, що висуває певні вимоги для проведення ефективного аналізу їх використання;

3) Необхідність диверсифікації бізнеспроцесів не пов'язані 3 підготовчими роботами на виробництво матеріалів (наприклад, асфальт, бетон тощо) та безпосередньо на виконання будівельно-монтажних робіт, що висуває вимоги до створення відповідної системи показників;

4) Аналіз витрат на окремих об'єктах будівництва та окремих стадіях виконання робіт має враховувати високу мобільність трудових ресурсів та техніки;

5) Технологічний взаємозв'язок та послідовність операцій як процеса будівництва в цілому так і окремих бізнес-процесів;

6) Висока матеріаломісткість виробництва висуває необхідність розробки ефективної системи аналіза і контроля за використанням матеріалів [4].

Методичні підходи управлінського аналізу спираються на особливості будівельної продукції як товара, обумовлені специфічністю виробничого процесу будівельної галузі, зокрема: тривалий термін виробничого циклу; вплив природно-кліматичних умов, що висуває необхідність врахування пов'язаних 3 цим ризиків; сезонний характер виробництва, що впливає на нерівномірність використання трудових ресурсів, техніки; індивідуальний та мелкосерійний характер виробництва.

До важливих рис будівельної продукції можна віднести наявність щільного взаємозв'язку 3 партнерами (замовниками, інвесторами, постачальниками, субпідрядниками тощо), що обумовлює враховувати потребу менеджерів у інформації та особливостях бізнес-процесів у будівництві включенням до системи показників відповідних індикаторів.

Однією 3 принципових відмінностей будівельної продукції як товару в порівнянні 3 
товарами масового або серійного виробництва є різні маркетингові аспекти: 1) продукція як товар за задумом його вмісту (проект), 2) продукція як товар в реальному виконанні (готовий об'єкт), 3) продукція як товар у вигляді будівельних послуг підрядчика, товар у супроводі.

Знаходячись у полі впливу ринкової економіки усі без винятку підприємства працюють під час постійних змін у зовнішньому середовищі, тому стійке функціонування у таких мінливих умовах потребує від керівництва максимального використання потенційних можливостей для адаптації або пристосування до оточуючих змін. Стійке функціонування підприємств можна охарактеризувати через такий важливий елемент як зв'язок «витрати обсяг - прибуток», які несуть вагомий вплив на зміну витрат, ціну, обсяг реалізації та величину прибутку. Тому такі показники як: формування власних засобів, середньо- i довгострокових джерел формування запасів і витрат, загальної величини основних джерел формування запасів i витрат, що визначають межі фінансової стійкості підприємства, прямо впливають на стійке функціонування підприємств [7, с. 12].

Розподіл бізнес-процесів будівельної організації залежно від їх спеціфікації за такими видами, як основні (доходостворюючі), забезпечуючі (інфраструктура) та стратегічного розвитку виявляється важливим в управлінні бізнес-процесами для дослідження сутності та характерних рис окремих бізнес-процесів та розробки певних вимог до індикаторів оцінки їх ефективності. На наш погляд, для вирішення завдань даної статті $є$ доцільним використання запропонованої в науковій літературі методики, що спрямована на визначення абсолютної, динамічної та порівняльної ефективності управління процесами на підприємстві [8, с.281282]. При формуванні системи показниківіндикаторів ефективності управлінського аналізу бізнес-процесів вважаємо доцільним зосередити увагу на абсолютній (статичній) ефективності, яка характеризує процеси поточного стану підприємства та управлінські (тактичні) рішення за результатами аналізу як комплексу варіативних дій для пристосування до економічної ситуації та на динамічній ефективності, яка $€$ характеристикою стратегічного управління та висвітлює основні тенденції розвитку (таблиця 2). Аналітичні узагальнення на рівні внутрішніх бізнес-процесів будівельних підприємств, а також зовнішнього бізнес-оточення для своєчасного відображення стану та динаміки ефективності управління видами діяльності підприємства впливають на успішне функціонування суб'єктів господарювання в ринковому середовищі.

Таблиця 2

Приклад формування системи показників за видами бізнес-процесів підприємств будівельної

\begin{tabular}{|c|c|c|c|}
\hline \multicolumn{4}{|c|}{ галузі* } \\
\hline \multirow{2}{*}{$\begin{array}{c}\text { Види бізнес- } \\
\text { процесів }\end{array}$} & \multirow[t]{2}{*}{ Характеристика } & \multicolumn{2}{|c|}{ Показники ефективності управління } \\
\hline & & $\begin{array}{c}\text { Тактичні (поточні) } \\
\text { рішення }\end{array}$ & Стратегічні рішення \\
\hline $\begin{array}{l}\text { Доходо- } \\
\text { створюючі }\end{array}$ & $\begin{array}{l}\text { Спрямовані на створення продукції } \\
\text { будівництва (робіт, послуг), } \\
\text { призначених на зовнішню } \\
\text { реалізацію і отримання доходу від } \\
\text { реалізації }\end{array}$ & $\begin{array}{l}\text { 1. Рівень ефективності } \\
\text { використання } \\
\text { будівельної техніки; } \\
\text { 2.Відхилення фактичних } \\
\text { витрат від кошторисних }\end{array}$ & $\begin{array}{l}\text { 1.Рентабельність продаж; } \\
\text { 2.Рівень впливу } \\
\text { сезонності виробництва, } \\
\text { ризику природно- } \\
\text { кліматичних умов } \\
\end{array}$ \\
\hline Забезпечуючі & $\begin{array}{l}\text { Спрямовані на створення продукції } \\
\text { (робіт, послуг), призначеної для } \\
\text { внутрішньго споживання та } \\
\text { забезпечення дієвості } \\
\text { інфраструктури будівельного } \\
\text { підприємства }\end{array}$ & $\begin{array}{l}\text { 1.Витрати на окремих } \\
\text { стадіях виконання робіт; } \\
\text { 2. Рівень мобільності } \\
\text { технічних ресурсів }\end{array}$ & $\begin{array}{l}\text { 1.Рівень диверсифікації } \\
\text { виробництва; } \\
\text { 2.Зміна частки витрат, } \\
\text { що спрямовується на } \\
\text { соціальний розвиток } \\
\text { працівників } \\
\end{array}$ \\
\hline Розвиваючі & $\begin{array}{l}\text { Спрямовані на розробку стратегії } \\
\text { підвищення } \\
\text { конкурентоспроможності } \\
\text { підприємства }\end{array}$ & $\begin{array}{l}\text { 1.Частка внутрішнього } \\
\text { ринку; } \\
\text { 2.Рівень } \\
\text { платоспроможності } \\
\text { підприємства }\end{array}$ & $\begin{array}{l}\text { 1.Зміни організаційної } \\
\text { структури; } \\
\text { 2. Достатність джерел } \\
\text { для формування запасів і } \\
\text { витрат }\end{array}$ \\
\hline
\end{tabular}

*Розроблено автором

Висновки i перспективи подальших досліджень. Дієвість наукового апарату управлінського аналізу в підготовці та прийнятті управлінських рішень посилюється застосуванням методик абсолютної (статичної) ефективності, що характеризує процеси поточного стану підприємства та динамічної ефективності, яка $\epsilon$ характеристикою 
стратегічного управління. Оскільки дані аспекти $\epsilon$ важливими для формування системи показників-індикаторів ефективності управлінького аналізу бізнес-процесів будівельного підприємства, нами запропоновано включати наступні показники за видами бізнес-процесів, зокрема, доходостворюючих (рівень ефективності використання будівельної техніки, ступінь впливу сезонності виробництва та ін.), забезпечуючих (рівень мобільності технічних ресурсів, рівень диверсифікації виробництва та ін.), розвиваючих (частка внутрішнього ринку, достатність джерел для формування запасів i витрат та ін.) бізнес-процесів для підприємств будівельної галузі.

При подальшому дослідженні необхідно зосередитись на розширенні системи показників 3 оцінки ефективності управління конкурентоспроможністю будівельного підприємства, яка значною мірою залежить від вміння максимально вдало застосовувати методику управлінського аналізу потенціалу підприємства.

\section{ПЕРЕЛІК ВИКОРИСТАНИХ ДЖЕРЕЛ}

1. Звєряков М.І. Глобалізація і деіндустріалізація: зміст, суперечності та способи їх розв'язання [Текст] / M.I. Звєряков // Економіка України. - 2017. - № 11(672). - С.3-17

2. Офіційний сайт Держкомітету статистики України / [Електронний ресурс]. - Режим доступу: https://ukrstat.org/uk/operativ/menu/menu_u/bud.htm

3. Кулікова Л.В. Сучасні тенденції розвитку будівельних підприємств [Текст] / Л.В. Кулікова // Інвестиції: практика та досвід. - 2017. - № 8. - С. 52-55

4. Пономарева Н.И. Особенности формирования учётно-аналитической системы в строительных организациях / Пономарева Н.И. // Успехи современного естествознания. - 2008. - № 7 . - С. $72-75$ [Електронний ресурс]. - Режим доступу: https://www.natural-sciences.ru/ru/article/view?id=10286

5. Петрищенко Н.А. Аналіз стану будівельної діяльності в регіонах України [Текст] / Н.А. Петрищенко // Економіка: реалії часу. - 2015. - № 4 (20). - С.192-197

6. Симионов Р.Ю. Анализ уровня управления и его влияния на показатели деятельности строительного предприятия [Текст] / Р.Ю. Симионов // Экономический анализ: теория и практика. - 2008. - № 7. - С.28-35

7. Аналітичні методи дослідження конкурентоздатності субєктів господарювання: монографія / Н.А. Волкова, Р.М. Волчек, О.М. Гайдаєнко, А.В. Коверда, А.Л. Коляда та ін.; Одеський національний економічний університет. - Одеса, Кримполіграфпапір, 2017. - 400 с.

8. Яркина Н.Н. Теоретические аспекты оценки эффективности управления предприятием / Яркина Н.Н. // Проблеми економіки. Науковий журнал. - 2014. - №3. - С. 279 - 285 [Електронний ресурс]. - Режим доступу: http://www.problecon.com/pdf/2014/3_0/279_285.pdf

\section{REFERENCES}

1. Zveriakov, M.I. (2017) Globalizatciia i deindustrializatciia: zmist, superechnosti ta sposobi ikh rozv’iazannia [Globalization and deindustrialization: content, contradictions and ways to solve them] Ekonomika Ukrä̈ni, 11(672), 317 [in Ukrainian].

2. Ofitciinii sait Derzhkomitetu statistiki Ukraïni [Official site of the State Statistics Committee of Ukraine]. ukrstat.org. Retrieved from https://ukrstat.org/uk/operativ/menu/menu_u/bud.htm [in Ukrainian].

3. Kulikova, L.V. (2017) Suchasni tendentciï rozvitku budivelnikh pidpriemstv [Modern trends in the development of construction companies] Investitciï: praktika ta dosvid, 8, 52-55 [in Ukrainian].

4. Ponomareva N.I. (2008) Osobennosti formirovaniia uchetno-analiticheskoi sistemy v stroitelnykh organizatciiakh [Features of the formation of the accounting and analytical system in construction organizations], 7. Retrieved from https://www.natural-sciences.ru/ru/article/view?id=10286 [in Ukrainian].

5. Petrishchenko, N.A. (2015). Analiz stanu budivelnoï diialnosti v regionakh Ukraïni [Analysis of the state of construction activity in the regions of Ukraine] Ekonomika: realiï chasu, 4 (20), 192-197 [in Ukrainian].

6. Simionov, R. (2008) Analiz urovnia upravleniia i ego vliianiia na pokazateli deiatelnosti stroitelnogo predpriiatiia [Analysis of the level of management and its impact on the performance of a construction company] Ekonomicheskii analiz: teoriia i praktika, 7, 28-35 [in Russian].

7. Volkova, N.A., Volchek, R.M, Gaidacnko, O.M., Koverda, A.V., Koliada, A.L.et al. (2017) Analitichni metodi doslidzhennia konkurentozdatnosti subektiv gospodariuvannia [Analytical methods of researching the competitiveness of business entities]. - Odesa: Krimpoligrafpapir [in Ukrainian].

8. Iarkina N.N. (2014) Teoreticheskie aspekty otcenki effektivnosti upravleniia predpriiatiem [Theoretical aspects of assessing the effectiveness of enterprise management], 3 . Retrieved from http://www.problecon.com/pdf/2014/3_0/279_285.pdf [in Russian]. 